\title{
Case-Control Analysis of Malaria Incidence in Sukamerindu Health Center Bengkulu City, Indonesia
}

\author{
Agung Sutriyawan', Tenike G. Miranda ${ }^{2}$, Ucu W. Somantri ${ }^{3}$, Hairil Akbar ${ }^{4}$ \\ ${ }^{1}$ Research Scholar, Bachelor Programme Public Health, Bhakti Kencana University, ${ }^{2}$ Research Scholar, Graduate \\ Program Public Health, University Respati of Indonesia, ${ }^{3}$ Research Scholar, Bachelor Programme Public Health, \\ Mathla ul Anwar University, ${ }^{4}$ Research Scholar, Graha Medika Institute of Health Science
}

\begin{abstract}
Background: Malaria is still one of the public health problems that can cause death primarily in high-risk groups. High incidence of malaria caused by unhealthy environment and patterns of Society behavior.

Objectives: Assessing the relationship between environmental factors and the society behavior factors with malaria incidence.

Method: This is a case-control study. Samples were taken using sampling purposive with criteria: Age 7-50 years and case groups were noted as clinical malaria patients. Data is collected by observing and filling out questionnaires. Risk factors are analyzed using the Chi-Square test, knowing the risks with the odds ratio. The dominant risk factors were analyzed using binary logistic regression.

Results: The variable associated with the malaria incident is ventilation $(0,000), 2.5$ (1.6-4.1), ceiling $(0,015), 1.7(1.1-2.7)$, puddles around the house $(0,005), 1.9(1.2-3.0)$, using of mosquito nets $(0,000), 4.1$ (2.4-6.4) and using mosquito repellent (0.001), $2,2(1,4-3,5)$.

Conclusion: The proven environmental factors associated with malaria incidents are ventilation, ceilings, and puddles around the house. The Society behavior factor associated with malaria incidents is using mosquito nets and using mosquito repellent. Proves that the use of mosquito nets is a major risk factor for malaria incidents, with a risk of 4.3 times greater in those who when sleeping at night do not use mosquito nets.
\end{abstract}

Keywords: Malaria, environment, society behavior, mosquito nets.

\section{Introduction}

Malaria is still one of the public health problems. The World Health Organization (WHO) has called for an ambitious commitment to eliminate malaria in 35 countries by the year 2030. All heads of state in the Asia-Pacific region have been committed to eradicating national malaria. Malaria programs are faced with the

\footnotetext{
Corresponding Author: Agung Sutriyawan

Research Scholar, Bachelor Programme Public Health, Bhakti Kencana University e-mail: agung.epid@gmail.com
}

challenge of malaria epidemiology changes. In this phase, an increase in the proportion of malaria imported and high-risk groups is often no longer children and pregnant women, but more associated with demographic risk factors and specific occupations for local arrangements. The transmission also becomes more geographically focused and is more likely to be reproduced through asymptomatic infections and non-falciparum. ${ }^{1}$

Each year more than 500 million people are infected with malaria and more than 1 million individuals die. Most cases in Africa and some Asian countries, Latin America, the Middle East, and some parts of Europe. The number of cases and deaths from malaria recorded in 2000 to $50 \%$ or more at the end of the year 2010 and 
$75 \%$ or more at the end of the year $2015 .^{2}$ Conditions in Indonesia tend to decline, but from 34 provinces in Indonesia, there are 8 provinces with Annual Parasite Incidence (API) numbers exceeding nationwide. The highest API took place in Papua (31.93) and West Papua (31.29) then East Nusa Tenggara, Maluku, North Maluku, Bengkulu, Bangka Belitung, and North Sulawesi.

Active and timely identification of related risk factors is crucial to target interventions to optimize malaria control. ${ }^{3}$ Environmental risk factors affecting mosquito density Anopheles are divided into two, which are outdoor environment consisting of air temperature, humidity, rain, wind, sunlight, water currents, water puddle, ditch, paddy field, bushes, and large animal livestock cage. While the risk factors inside the house consist of gauze wire on ventilation, wall density, ceiling and clothes hanging. ${ }^{4}$

Bengkulu is one of the provinces whose API numbers still exceed national figures. Based on the health profile of Bengkulu Province in 2016 the number of malaria sufferers without blood supply is as much as 33,814 , while with a blood supply test of 28,333 sufferers and test results there is 2,631 positive malaria. The highest case in North Bengkulu Regency was 1097 cases and the lowest in Heroiang district amounted to 4 cases, while in the city of Bengkulu amounted to 96 cases and 1 of them died. The city of Bengkulu kept the position to 6 highest in 10 regencies in Bengkulu Province whereas the city of Bengkulu is an urban area and Regency/ city with the most advanced economy in 10 districts/ cities and is mostly urban areas. Three health centers in Bengkulu with sufferers of the highest suspect malaria is Puskesmas Sukamerindu (1208 cases). There were increased cases of malaria in Puksesmas Sukamerindu in 2015 amounted to 926 sufferers, and increased in the year 2016 to 1,208 cases.

\section{Material and Method}

The design used in this study is quantitative casecontrol. Case population, all people who were declared clinical malaria based on data at the Sukamerindu Public Health Center. While control is taken from the case of neighbors who are free of malaria. The total sample of cases is 150 cases and 150 controls. Samples were taken using purposive sampling with the following criteria: Ages 7-50 years and case groups were recorded as clinical malaria patients. Data collection is done by two method, namely: first, interviews with the use of questionnaires, made as much as possible in a familiar atmosphere so that the interview can run smoothly and managed to get the information expected. Secondly, the observation method is conducted by researchers formally and informally to observe the activities in the field.

Data were collected by observing environmental variables: ventilation, walls, ceilings, standing water around the house, trenches around the house, and bushes around the house. While society behavior factors are taken by filling out questionnaires and interviews with respondents. Risk factors were analyzed using the chisquare test, to determine the magnitude of the risk using the Odds ratio (OR). After that, a multivariate analysis was performed using multiple logistic regression.

\section{Findings:}

Tabel 1. Characteristics of Respondents in the Study

\begin{tabular}{|c|c|c|}
\hline Characteristics & $\mathrm{n}=\mathbf{3 5 0}$ & Percentage (\%) \\
\hline \multicolumn{3}{|l|}{ Age (years) } \\
\hline$<10$ & 14 & 4,7 \\
\hline $10-19$ & 55 & 18,3 \\
\hline $20-29$ & 97 & 32,3 \\
\hline $30-39$ & 60 & 20,0 \\
\hline $40-50$ & 74 & 24,7 \\
\hline \multicolumn{3}{|l|}{ Sex } \\
\hline Men & 178 & 59,3 \\
\hline Women & 122 & 40,7 \\
\hline \multicolumn{3}{|l|}{ Education } \\
\hline No school & 58 & 19,3 \\
\hline Elementary school & 62 & 20,7 \\
\hline Middle School & 77 & 25,7 \\
\hline High school & 52 & 17,3 \\
\hline College & 51 & 17,0 \\
\hline \multicolumn{3}{|l|}{ Job } \\
\hline Labor & 43 & 14,3 \\
\hline Farmers & 46 & 15,3 \\
\hline Traders & 50 & 16,7 \\
\hline General employees & 51 & 17,0 \\
\hline Government employees & 16 & 5,3 \\
\hline Other & 94 & 31,3 \\
\hline
\end{tabular}

The results showed most of the participants aged between 20-29 years (32.3\%) and men (59.3\%). Most of the participants were low education and as workers. 
Table 2. Chi-Square Test of Environmental Factors Related To Malaria Incidence

\begin{tabular}{|c|c|c|c|c|c|c|c|}
\hline \multirow{3}{*}{ Environmental Factor } & \multicolumn{4}{|c|}{ Malaria Incidence } & \multirow{3}{*}{ P-value } & \multirow{2}{*}{\multicolumn{2}{|c|}{ OR(95\% CI) }} \\
\hline & \multicolumn{2}{|c|}{ Case } & \multicolumn{2}{|c|}{ Control } & & & \\
\hline & $\mathrm{n}=\mathbf{1 5 0}$ & $\%$ & $n=150$ & $\%$ & & Lower & Upper \\
\hline \multicolumn{5}{|l|}{ Ventilation } & \multirow{3}{*}{$0,000^{*}$} & \multirow{3}{*}{\multicolumn{2}{|c|}{$\begin{array}{c}2,588 \\
1,625-4,122\end{array}$}} \\
\hline Not Qualify & 92 & 61,3 & 57 & 38,0 & & & \\
\hline Qualify & 58 & 38,7 & 93 & 62,0 & & & \\
\hline \multicolumn{5}{|l|}{ Wall } & \multirow{3}{*}{0,105} & \multirow{3}{*}{\multicolumn{2}{|c|}{$\begin{array}{c}1,456 \\
0,923-2,295\end{array}$}} \\
\hline Not Qualify & 78 & 52,0 & 64 & 42,7 & & & \\
\hline Qualify & 72 & 48,0 & 86 & 57,3 & & & \\
\hline \multicolumn{5}{|l|}{ Ceiling } & \multirow{3}{*}{$0,015^{*}$} & \multirow{3}{*}{\multicolumn{2}{|c|}{$\begin{array}{c}1,763 \\
1,114-2,788\end{array}$}} \\
\hline Not Qualify & 80 & 53,3 & 59 & 39,7 & & & \\
\hline Qualify & 70 & 46,7 & 91 & 60.7 & & & \\
\hline \multicolumn{5}{|c|}{ There are puddles around the house } & \multirow{3}{*}{$0,015^{*}$} & \multirow{3}{*}{\multicolumn{2}{|c|}{$\begin{array}{c}1,758 \\
1,113-2,778\end{array}$}} \\
\hline Yes & 88 & 58,7 & 67 & 44,7 & & & \\
\hline Not & 62 & 41,3 & 83 & 55,3 & & & \\
\hline \multicolumn{5}{|c|}{ There are trenches around the house } & \multirow{3}{*}{$0,005^{*}$} & \multirow{3}{*}{\multicolumn{2}{|c|}{$\begin{array}{c}1,930 \\
1,215-3,068\end{array}$}} \\
\hline Yes & 97 & 64,7 & 73 & 48,7 & & & \\
\hline Not & 53 & 35,4 & 77 & 41,3 & & & \\
\hline \multicolumn{5}{|c|}{ There are bushes around the house } & \multirow{3}{*}{0,406} & \multirow{3}{*}{\multicolumn{2}{|c|}{$\begin{array}{c}1,218 \\
0,64-1,942\end{array}$}} \\
\hline Yes & 61 & 40,7 & 54 & 36,0 & & & \\
\hline Not & 89 & 59,3 & 96 & 64,0 & & & \\
\hline
\end{tabular}

* Significant $<0,05$

The study showed that environmental factors that were significantly related to the malaria incident were kolowa ventilation $(\mathrm{p}=0,000), \mathrm{OR}=2,5(1,6-4.1)$, ceiling $(\mathrm{p}=0,015), \mathrm{OR}=1.7(1,7-2.7)$, and puddles around the house $(\mathrm{P}=0,005), \mathrm{OR}=1.9(1,2-3.0)$. While the wall, life around the house, bushes around the house are not proven to be a risk factor for malaria incidents.

Tabel 3. Chi-Square Test of Society Behavior Factors Related To Malaria Incidence

\begin{tabular}{|c|c|c|c|c|c|c|c|}
\hline \multirow{3}{*}{ Society Behavior Factors } & \multicolumn{4}{|c|}{ Malaria Incidence } & \multirow{3}{*}{ P-value } & \multirow{2}{*}{\multicolumn{2}{|c|}{ OR(95\% CI) }} \\
\hline & \multicolumn{2}{|c|}{ Case } & \multicolumn{2}{|c|}{ Control } & & & \\
\hline & $n=150$ & $\%$ & $n=150$ & $\%$ & & Lower & Upper \\
\hline \multicolumn{5}{|l|}{ Knowledge } & \multirow{3}{*}{0,354} & \multirow{3}{*}{\multicolumn{2}{|c|}{$\begin{array}{c}1,240 \\
0,787-1,956\end{array}$}} \\
\hline High & 86 & 57,3 & 78 & 52,0 & & & \\
\hline Low & 64 & 42,7 & 72 & 48,0 & & & \\
\hline \multicolumn{5}{|l|}{ Attitude } & \multirow{3}{*}{0,907} & \multirow{3}{*}{\multicolumn{2}{|c|}{$\begin{array}{c}1,028 \\
0,649-1,627\end{array}$}} \\
\hline Positive & 63 & 42,0 & 62 & 41,3 & & & \\
\hline Negative & 78 & 58,0 & 88 & 58,7 & & & \\
\hline \multicolumn{5}{|l|}{ Using mosquito nets } & \multirow{3}{*}{$0,000^{*}$} & \multirow{3}{*}{\multicolumn{2}{|c|}{$\begin{array}{c}4,011 \\
2,480-6,487\end{array}$}} \\
\hline Yes & 103 & 68,7 & 53 & 35,3 & & & \\
\hline Not & 47 & 31,3 & 97 & 64,7 & & & \\
\hline
\end{tabular}




\begin{tabular}{|c|c|c|c|c|c|c|c|}
\hline \multirow{3}{*}{ Society Behavior Factors } & \multicolumn{4}{|c|}{ Malaria Incidence } & \multirow{3}{*}{ P-value } & \multirow{2}{*}{\multicolumn{2}{|c|}{ OR(95\% CI) }} \\
\hline & \multicolumn{2}{|c|}{ Case } & \multicolumn{2}{|c|}{ Control } & & & \\
\hline & $\mathrm{n}=\mathbf{1 5 0}$ & $\%$ & $\mathrm{n}=\mathbf{1 5 0}$ & $\%$ & & Lower & Upper \\
\hline \multicolumn{5}{|l|}{ Using mosquito repellent } & \multirow{3}{*}{$0,001 *$} & \multirow{3}{*}{\multicolumn{2}{|c|}{$\begin{array}{c}2,250 \\
1,418-3,572\end{array}$}} \\
\hline Yes & 91 & 60,7 & 61 & 40,7 & & & \\
\hline Not & 59 & 39,4 & 89 & 59,3 & & & \\
\hline \multicolumn{5}{|c|}{ Using long sleeves when out of the house at night } & \multirow{3}{*}{0,130} & \multirow{3}{*}{\multicolumn{2}{|c|}{$\begin{array}{c}1,424 \\
0,900-2,251\end{array}$}} \\
\hline Yes & 91 & 60,7 & 78 & 52,0 & & & \\
\hline Not & 59 & 39,3 & 72 & 48,0 & & & \\
\hline \multicolumn{5}{|c|}{ The habit of hanging dirty clothes } & \multirow{3}{*}{0,296} & \multirow{3}{*}{\multicolumn{2}{|c|}{$\begin{array}{c}1,276 \\
0,808-2,014\end{array}$}} \\
\hline Yes & 88 & 58,7 & 79 & 52,7 & & & \\
\hline Not & 62 & 41,3 & 71 & 47,3 & & & \\
\hline
\end{tabular}

* Significant $<0,05$

The study showed that the society's behavior factors that were significantly related to the malaria incident were using mosquito nets $(\mathrm{P}=0,000), \mathrm{OR}=4.1(2$, 4-6.4), and using mosquito repellent $(\mathrm{p}=0.001)$, OR
$=2.2$ (1.4-3.5). While knowledge, attitude, using long sleeves when out of the house at night, and habit of hanging dirty clothes are not proven to be a risk factor for malaria incidents.

Table 4. Multiple Logistic Regression Test Results For The Final Risk Factor Related of Malaria Incidence

\begin{tabular}{|c|c|c|c|c|c|}
\hline \multirow{2}{*}{ Risk Factor } & \multirow{2}{*}{$\mathbf{r}^{2}$} & \multirow{2}{*}{ P-value } & \multirow{2}{*}{ OR } & \multicolumn{2}{|c|}{ 95\% CI for EXP (B) } \\
\hline & & & & Lower & Upper \\
\hline Ventilation & 0,071 & $0,000^{*}$ & 2,892 & 1,692 & 4,755 \\
\hline Trenches around the house & 0,034 & $0,005^{*}$ & 2,097 & 1,250 & 3,517 \\
\hline Using of mosquito nets & 0,143 & $0,000 *$ & 4,362 & 2,594 & 7,335 \\
\hline Using mosquito repellent & 0,053 & $0,008^{*}$ & 1,981 & 1.191 & 3,296 \\
\hline
\end{tabular}

* Significant $<0,05$

Multivariate analyses were conducted to view several risk factors that were jointly associated with malaria incidents. The dominant risk factors for malaria incidents are using mosquito nets.

\section{Discussion}

Environmental Factors: The study was conducted to assess the physical environmental factors of the home consisting of ventilation, Wall, and Ceiling. In the population, studies proved that ventilation is a risk factor for malaria events. Their risk of suffering from malaria if not attaching a gauze wire to the ventilation is doubling. The results of the survey have mostly used gauze on home ventilation. But in some houses that have been installed wire gauze, researchers found damaged wire gauze such as perforated and torn Karna has long been not replaced. But there is still also a house that does not use a gauze wire in ventilation, although it uses only partially ventilation as it is installed only in the room only. A study in Banjarnegara, Indonesia suggests that people who do not put mosquito nets in their home vents have significantly higher chances of having malaria. Wire netting is a barrier against mosquitoes entering the house. $^{5}$

This study proves that the ceiling is a risk factor for malaria events. With a risk of 1.7 times greater in those 
who live at home do not have a ceiling. Another study in Indonesia proved the same, in-house environmental factors that do not have a significant risk of malaria incidence is the condition of the wall.,

Environmental factors outside the home are proving to be a risk factor for malaria events are puddles around the house and life around the house. Studies in Uganda suggest that malaria-repellent mosquitoes breed in puddles and are often found near homes especially in rural communities in endemic countries. This is an indication that conditions that support the breeding of mosquitoes are allowed in the community. ${ }^{8}$ Another study in Africa showed that the productivity of the highest Anopheles larva was observed in paddy fields, agricultural moats, and irrigation wells. ${ }^{9}$

The results of observation, some puddle of water such as the former Fish pond and the former pit around the respondent's house there is a mosquito larva, but this study is not done further to identify whether the larva found is a mosquito repellent Anopheles or not. Observation results are also obtained in almost every house adjacent to the ditch/ditch. When the trenches observation does not flow well so there are a lot of inundated trenches that could potentially be a place for mosquitoes to be missed.

This study cannot prove that a tightly-wall can prevent the occurrence of malaria. The results of the survey, in general, the wall condition of many respondents house made of concrete or cement. In some homes based on boards, some respondents closed the holes with tape or paper pasted between the boards so that mosquitoes did not go through the holes. The study also could not prove the bush around the house was a risk factor for malaria events.

The Gordon model known by a Trias epidemiology of infectious diseases is influenced by three main factors namely the host, agent, and environment. ${ }^{10}$ The intended environment includes sanitation, the physical environment of the home, and the environment around the house. Poor sanitation is not only directly related to infectious diseases but can also affect the health of children. ${ }^{11}$ The physical environment of the home such as ventilation and ceilings, as well as the environment that exists outside the home is closely related to the incidence of infectious diseases such as malaria.

Society Behavior Factors: The study also assessed the relationship of community behavior factors. The study reported that knowledge and attitudes were not proven significantly with the incidence of malaria. The study was conducted in urban areas, with most of the respondents well-educated, so that society has a good knowledge of malaria. Knowledge of taking medication, malaria test, and vector control by spraying at home. It is important to keep a clean trench around the house so that people are protected from illness. ${ }^{12}$ The study in South Africa stated differently, that knowledge and attitudes were significantly related to the incidence of infectious diseases, one of which was malaria. ${ }^{13}$

This study proved that the use of mosquito nets was significantly related to malaria events. Some previous studies have expressed the use of mosquito nets associated with malaria events. ${ }^{14,15}$ A double logistic regression test proves that the use of mosquito nets is a major risk factor of malaria. Chances of suffering from malaria in those who sleep at night do not use a mosquito net of 4.3 times larger. A previous study in Central Java province, Indonesia expressed sleep under mosquito nets is a technique to protect from mosquito bites. In this study, people who slept under the mosquito net had a lower chance (4.6 times) suffering from malaria than those who did not. ${ }^{16}$. Another study conducted in ChinaVietnam suggested that the effect of the control-based prevention measures vector. Those who do not sleep under the mosquito nets have more than 5 times higher chances of experiencing unsymptomatic infections compared to those sleeping under the mosquito nets. ${ }^{17}$

The study also proved that Using mosquito repellent is a risk factor for malaria. The respondent did not use mosquito repellent because it does not like the smell of mosquito repellent. Studies in India have said that the use of mosquito repellent is effective in preventing mosquito bites. This study can not prove Using long sleeves when out of the house at night and the Habit of hanging dirty clothes is significantly related to malaria.

\section{Conclusion}

The proven environmental factors related to malaria incidents are ventilation, ceiling, and puddles around the house. The Society's proven behavior factors related to malaria incidents are using mosquito nets and using mosquito repellent. This study proves that using mosquito nets is a major risk factor for malaria incidents, with a risk magnitude of 4.3 times greater in those who do not use mosquito nets during nighttime sleep. 
Conflict of Interest: All authors do not have a conflict of interest to declare related to research and work.

Source of Funding: The source of this research costs from self.

Ethical Clearance: The study was approved by the institutional Ethical Board of Bhakti Kencana University.

\section{References}

1. Herdiana H, Cotter C, Coutrier FN, Zarlinda I, Zelman BW, Tirta YK, et al. Malaria risk factor assessment using active and passive surveillance data from Aceh Besar, Indonesia, a low endemic, malaria elimination setting with Plasmodium knowlesi, Plasmodium vivax, and Plasmodium falciparum. Malar J [Internet]. 2016;15(1):468. Available from: https://link.springer.com/ article/10.1186/s12936-016-1523-z

2. Organization WH. World malaria report 2015. World Health Organization; 2016.

3. Rulisa S, Kateera F, Bizimana JP, Agaba S, Dukuzumuremyi J, Baas L, etal. Malaria prevalence, spatial clustering and risk factors in a low endemic area of Eastern Rwanda: a cross sectional study. PLoS One [Internet]. 2013;8(7):e69443. Available from: https://journals.plos.org/plosone/ article?id=10.1371/journal.pone.0069443

4. Arsin AA. Malaria in Indonesia reviews epidemiological aspects. Makassar, masagenapress. 2012;

5. Sulistyawati, Rokhmayanti, Fajar. Malaria Risk Factors in Banjarnegara, Indonesia: A Matched Case-Control Study. J UOEH [Internet]. 2020;42(2):161-6. Available from: https://pubmed. ncbi.nlm.nih.gov/32507839/

6. Irawati I, Ishak $\mathrm{H}$, Arsin A. Environmental Characteristics of Malaria Patients in Bulukumba Regency. Afiasi J Kesehat Masy [Internet]. 2019;2(3):73-7. Available from: http://afiasi. unwir.ac.id/index.php/afiasi/article/view/47

7. Wiwoho FH, Hadisaputro S, Suwondo A. Risk Factors for Malaria Incidence in Cluwak Health Center and Dukuhseti Health Center Pati. J Epidemiol Kesehat Komunitas [Internet]. 2018;1(1):1-8. Available from: https://www.neliti. com/publications/301965/faktor-risiko-kejadian- malaria-di-puskesmas-cluwak-dan-puskesmasdukuhseti-kabup

8. Musoke D, Miiro G, Ndejjo R, Karani G, Morris $\mathrm{K}$, Kasasa $\mathrm{S}$, et al. Malaria prevention practices and associated environmental risk factors in a rural community in Wakiso district, Uganda. PLoS One [Internet]. 2018;13(10):e0205210. Available from: https://pubmed.ncbi.nlm.nih.gov/30300396/

9. Matthys B, N'Goran EK, Koné M, Koudou BG, Vounatsou P, Cissé G, et al. Urban agricultural land use and characterization of mosquito larval habitats in a medium-sized town of Côte d'Ivoire. J Vector Ecol [Internet]. 2006 Dec;31(2):319-33. Available from: https://pubmed.ncbi.nlm.nih.gov/17249350/

10. Sumampouw OJ. Eradication of Infectious Diseases [Internet]. Deepublish; 2017. Available from: https://books.google.co.id/books?hl=id \& $\mathrm{l} r=\& \mathrm{id}=\mathrm{UkZHDwAAQBAJ} \quad \&$ oi=fnd \& pg=PR6 \& dq=faktor+risiko+penyakit+menular \& ots=Oqw1Yp9QES \& sig=OtaC4kXKDfxc5rBWMGUY3OCehg \& redir_esc $=\mathrm{y} \# \mathrm{v}=$ onepage $\&$ $\mathrm{q}=$ faktor risiko penyakit menular \& $\mathrm{f}=$ false

11. Sutriyawan A, Nadhira CC. Kejadian Stunting Pada Balita Di Upt Puskesmas Citarip Kota Bandung. J Kesmas (Kesehatan Masyarakat) Khatulistiwa [Internet]. 2020;7(2):79-88. Available from: http:// openjurnal.unmuhpnk.ac.id/index.php/JKMK/ article/view/2072

12. Molineros-Gallón LF, Hernández-Carrillo M, Castro-Espinosa J, Trujillo de Cisneros E. [Knowledge, attitudes, perceptions and community practices for urban malaria. Tumaco, Colombia]. Rev Salud Publica (Bogota) [Internet]. 2018 ;20(1):82-8. Available from: https://pubmed.ncbi. nlm.nih.gov/30183889/

13. Govere J, Durrheim D, la Grange K, Mabuza A, Booman M. Community knowledge and perceptions about malaria and practices influencing malaria control in Mpumalanga Province, South Africa. S Afr Med J [Internet]. 2000 Jun;90(6):6116. Available from: https://pubmed.ncbi.nlm.nih. gov/10918892/

14. Durnez L, Pareyn M, Mean V, Kim S, Khim N, Menard D, et al. Identification and characterization of areas of high and low risk for asymptomatic malaria infections at sub-village level in Ratanakiri, Cambodia. Malar J [Internet]. 2018;17(1):27. Available from: https://pubmed.ncbi.nlm.nih. gov/29334956/ 
15. Belete EM, Roro AB. Malaria prevalence and its associated risk factors among patients attending Chichu and Wonago Health Centres, South Ethiopia. J Res Health Sci [Internet]. 2016;16(4):185. Available from: https://pubmed. ncbi.nlm.nih.gov/28087849/

16. Cahyaningrum P, Sulistyawati S. Malaria risk factors in Kaligesing, Purworejo district, central Java province, Indonesia: a case-control study. J
Prev Med Public Heal [Internet]. 2018;51(3):148. Available from: https://pubmed.ncbi.nlm.nih. gov/29886710/

17. Zhao Y, Zeng J, Zhao Y, Liu Q, He Y, Zhang J, et al. Risk factors for asymptomatic malaria infections from seasonal cross-sectional surveys along the China-Myanmar border. Malar J [Internet]. 2018;17(1):247. Available from: https://pubmed. ncbi.nlm.nih.gov/29973194/ 